\title{
Rates and magnitudes of paraglacial fan formation in the Garhwal Himalaya: implications for landscape evolution
}

\author{
Lewis A. Owen ${ }^{\mathrm{a}, *}$, Milap C. Sharma ${ }^{\mathrm{b}}$ \\ ${ }^{a}$ Department of Earth Sciences, University of California, Riverside, CA 92521 0423, USA \\ b Department of Geography, Government College Kullu, Himachal Pradesh 175101, India \\ Received 19 February 1996; revised 5 January 1997; accepted 1 March 1998
}

\begin{abstract}
The development of paraglacial fans, studied in the upper Bhagirathi valley, Garhwal Himalaya, northern India, relates to the retreat of the Gangotri Glacier over the last 200 years. These fans demonstrate the speed by which mass movement and fluvial processes may lead to the modification and readjustment of the Himalayan landscapes during deglaciation. The paraglacial fans in this region grew within approximately 100 years of deglaciation, and there after were modified by small debris flows and entrenched by fluvial incision. On the basis of the preservation of moraines which were deposited during the Last Glacial, total resedimentation of glacial sediments by mass movement and fluvial processes is estimated to occur over approximately 100,000 years in this region. A knowledge of the magnitude and frequency of development of paraglacial fans is essential for hazard mitigation and management in Himalayan environments where glaciers are presently retreating and are likely to retreat in the near future if global warming occurs. (C) 1998 Elsevier Science B.V. All rights reserved.
\end{abstract}

Keywords: paraglacial fan; Garhwal Himalaya; glaciation; debris flows; resedimentation; Quaternary

\section{Introduction}

The term paraglacial was first used by Ryder (1971a,b) to explain the formation of alluvial fans in south-central British Columbia. Ryder related these fans to the resedimentation of glacial deposits by fluvial and mass movement processes. On the basis of the style and age of proglacial sediments on Baffin Island and in British Columbia, Church and Ryder (1972) defined the term paraglacial as being nonglacial processes that are directly conditioned by

\footnotetext{
* Corresponding author.
}

glaciation. They also used the term to categorise landforms that were the product of paraglacial processes, and to describe the period of time following deglaciation when landforms were adjusting to the new conditions.

In the Himalaya, a combination of steep slopes, thick deposits of glacial sediments and large discharges from rivers, have resulted in paraglacial processes producing major landscape changes associated with deglaciation. Mass movement processes in the landscape evolution of the Karakoram Mountains and Great Himalaya in Northern Pakistan throughout late Quaternary times were emphasised by Owen (1989, 1991). In addition, by comparing three val- 
leys which had undergone different degrees of glaciation, Owen et al. (1995a) showed that paraglacial sedimentation was relatively rapid and was one of the major factors in the evolution of glaciated valleys in the Lahul Himalaya in Northern India. Similarly, in the Garhwal Himalaya of India, Sharma and Owen (1996) showed that paraglacial processes were important in the evolution of glaciated valleys. Because of control over poor dating, the exact timing and rates of resedimentation have yet to be calculated.

To provide some control on the rapidity of paraglacial processes in the landscape evolution within Himalayan valleys, paraglacial fans in the upper Bhagirathi valley in the Garhwal Himalaya were examined (Fig. 1). Here, good chronologies and reconstructions of glacial retreat have been established (Sharma and Owen, 1996) which help quantify the rates of landscape evolution and readjustment by paraglacial processes. This paper will describe the timing and rates of paraglacial processes in the upper Bhagirathi valley, thus providing a framework for the evolution of the Himalayan landscapes.

\section{Geomorphological setting}

The study area, situated in the upper Bhagirathi valley in the Garhwal Himalaya, Northern India (Fig. 1), is tectonically active and is undergoing rapid uplift (Owen et al., 1995b, 1996b; Metcalfe, 1993), with elevations ranging from $1500 \mathrm{~m}$ to $7075 \mathrm{~m}$ a.s.l. The climate is influenced by the southwest Indian monsoon, with an average annual precipitation of $1550 \mathrm{~mm}$. Valley aspect and altitude, however, produce a variety of microclimates (Sharma and Owen, 1996). The main flora comprises Quercus incana, Rhododenron arboreum, Pieris ovalifolia, and $\mathrm{Ce}$ drus deodara, which are tolerant of long-lying snow cover, and Artemisia maritima, Pinus excelsa, $P$. geradiana and Betula utelis which occur as pioneers on scree and steep slopes (Schweinfurth, 1968). The upper tree-line in Garhwal is represented by B. utelis at an altitude of $4150 \mathrm{~m}$ a.s.l.

The glaciers within the region are of high activity type, and have source areas at high altitudes and equilibrium line elevations ranging from 4510 to
$5390 \mathrm{~m}$ a.s.l. (Sharma and Owen, 1996). The environment of glacial deposition is dominated by supraglacial debris transport pathways, similar to Ghulkin-type glaciers described by Owen and Derbyshire (1989) in the Karakoram Mountains. Throughout the higher parts of the region, glacial meltwater dominates the fluvial system. Mass movement is common, initiated by heavy monsoon rains and active fluvial incision along the lower steep valley slopes (Owen et al., 1995b, 1996b).

\section{Methods}

The best map of this region was at a scale of 1:150,000 (Huber, 1985), because detailed base maps and aerial photographs are not available. Base maps were, therefore, constructed at a scale of 1:5000 using reconnaissance survey techniques that included plane tabling and chain surveys. Standard geomorphological mapping was undertaken using the methods described by Derbyshire and Owen (1990) and Cooke and Doornkamp (1990). Detailed geomorphological maps were produced for an area in the upper Bhagirathi valley, extending for approximately $5 \mathrm{~km}$ east of Bhujbas to the snout of the Gangotri Glacier (Figs. 1 and 2: Sharma and Owen, 1996). Morphostratigraphy was used as a primary basis for correlating and supported by the relative dating techniques of Perrott and Goudie (1984), Burbank and Kang (1991) and Burke and Birkeland (1979). The relative dating techniques included the frequency of boulders, the ratio of fresh to weathered boulders, and boulder relief. Other relative methods included the number of species of vascular plants and the percentage of plant cover, and the number and diameter of lichen species. Former thicknesses of the ice and the sequence of retreat were reconstructed using the established chronology, the mapped positions of the former glacier and levelled elevations of moraines. The formation and growth of the paraglacial fans in this area was reconstructed using the geomorphological maps in relation to the timing of glacier retreat. The extent of one of the large fans was calculated for different time periods using landforms and sediments, and the reconstruction of the former position of the Gangotri Glacier, and dated on the basis of relative weathering criteria. The volume of sediment 


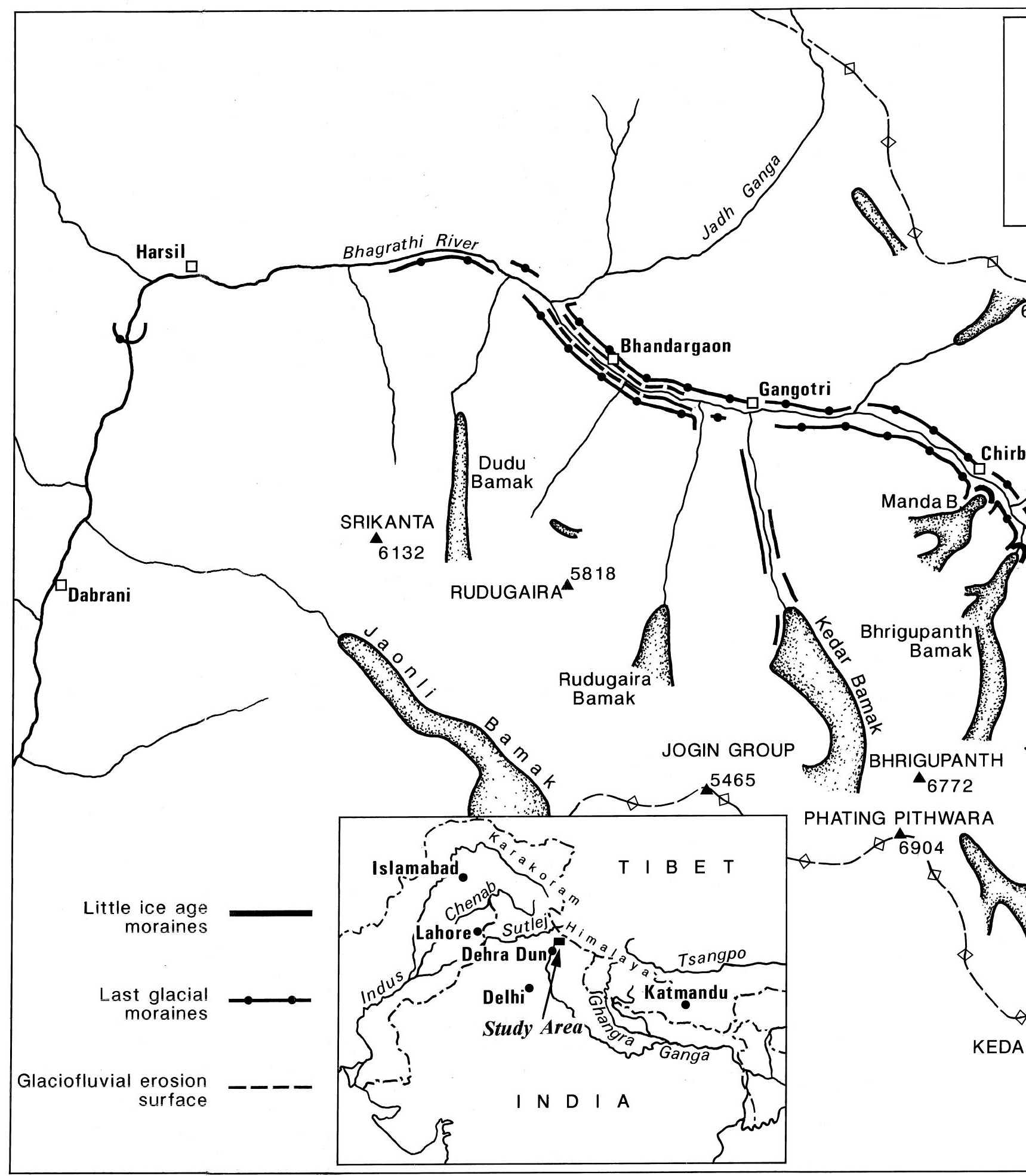

Fig. 1. Location map of study area, showing the main moraines. 



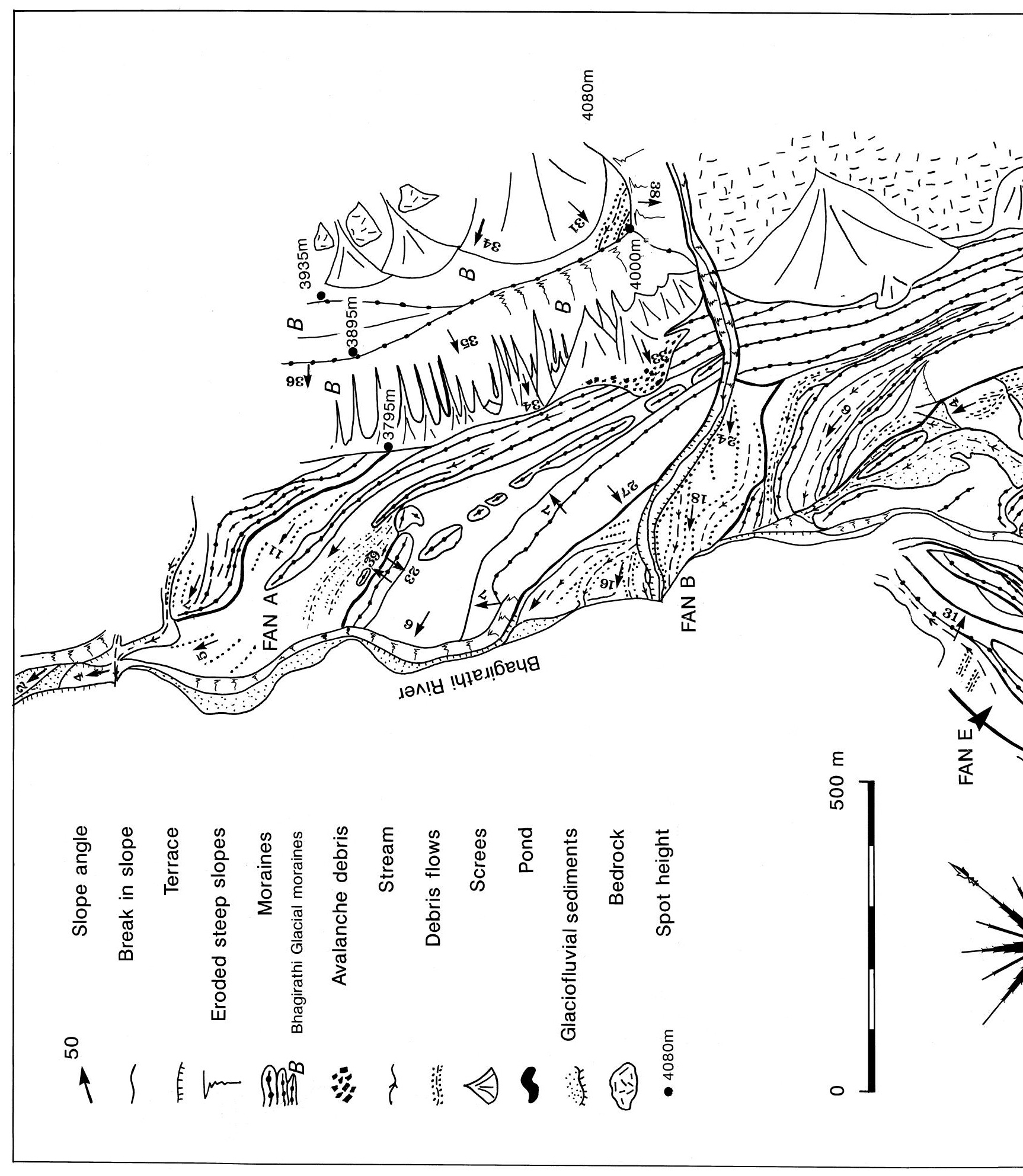



deposited was not calculated because the thickness of the fan could not be determined.

The sedimentological characteristics of debris flow and till deposits were described in the field and samples were collected for particle size analysis. The analysis of particle size was undertaken by a combination of wet sieving using the method of Lee (1991) for grain sizes between $3 \mathrm{~mm}$ and $63 \mu \mathrm{m}$, and SediGraph analysis for grain sizes below $63 \mu \mathrm{m}$.

\section{Results}

Three major sets of landforms are dominant within the study area and are important to the understanding of the paraglacial history of the region. Each set of landforms are discussed in turn.

\subsection{Moraines}

Impressive lateral moraines are present along the valley sides of the Bhagirathi valley (Fig. 3). These extend from altitudes of $>4200 \mathrm{~m}$ a.s.l. above the Gangotri Glacier, down the Bhagirathi valley to an altitude of ca. $3300 \mathrm{~m}$ west of Gangotri village, where they become discontinuous to Jhala, approximately $40.5 \mathrm{~km}$ from the present snout of Gangotri Glacier. These moraines are well vegetated with abundant Potentilla microphylla. The surface of the Gangotri Glacier is inset into these lateral moraines and has eroded steep slopes of loose debris that rise $120 \mathrm{~m}$ to the crest of the highest lateral moraine. These large lateral moraines form a series of discontinuous ablation valleys which are filled with scree, debris flow and lacustrine sediments. Sharma and Owen (1996) attribute these moraines to the Bhagirathi Glacial Stage, which occurred during the Last Glacial and reached its maximum extent at approximately $63 \mathrm{ka}$.

A series of sharp crested moraines are inset into the lateral moraine of the Bhagirathi Glacial Stage and can be traced down valley to Bhujbas. In places, the moraine ridges are buried beneath debris flows and fluvial sediments. Elsewhere the moraines have been eroded by migrating glaciofluvial and tributary valley streams, and by mass movement processes. Impressive palaeochannels have been preserved, and permit accurate reconstructions of former positions

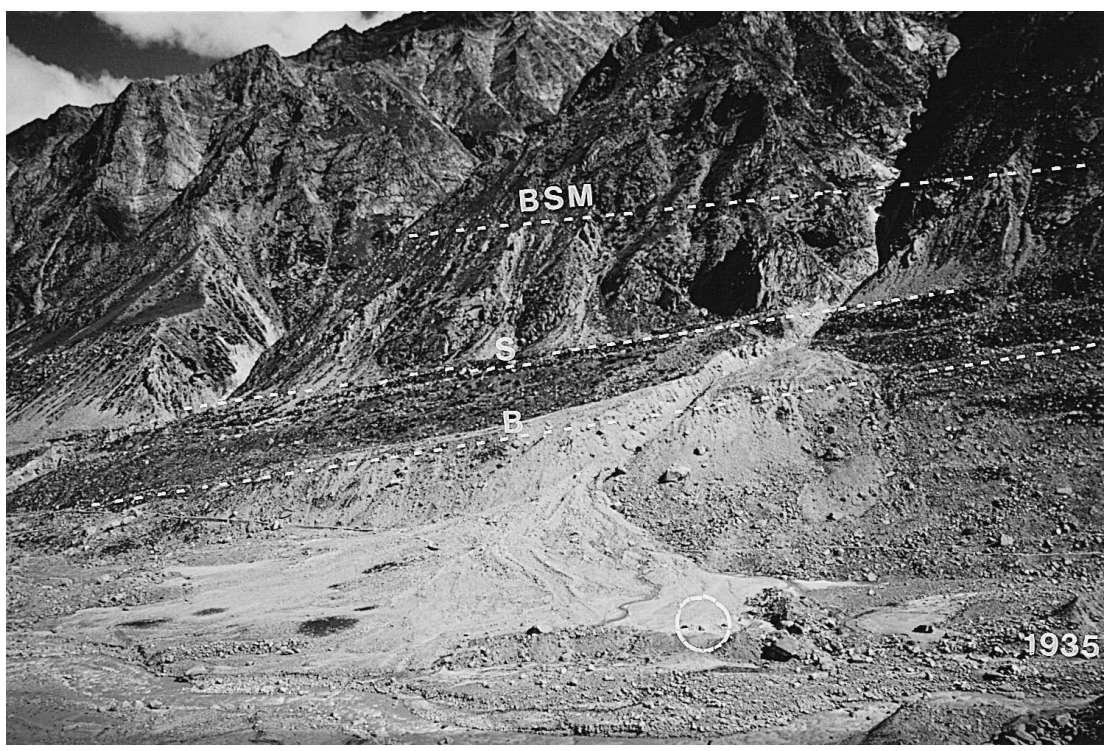

Fig. 3. View looking NNW at Fan C on the northern side of the Bhagirathi valley. The moraines labelled BSM refer to the Bhagirathi Glacial Stage, S the Shivling Advance and B the Bhujbas Advance. The circle encloses a camp of seven tents for scale. The moraines below the camp where formed in 1971. 


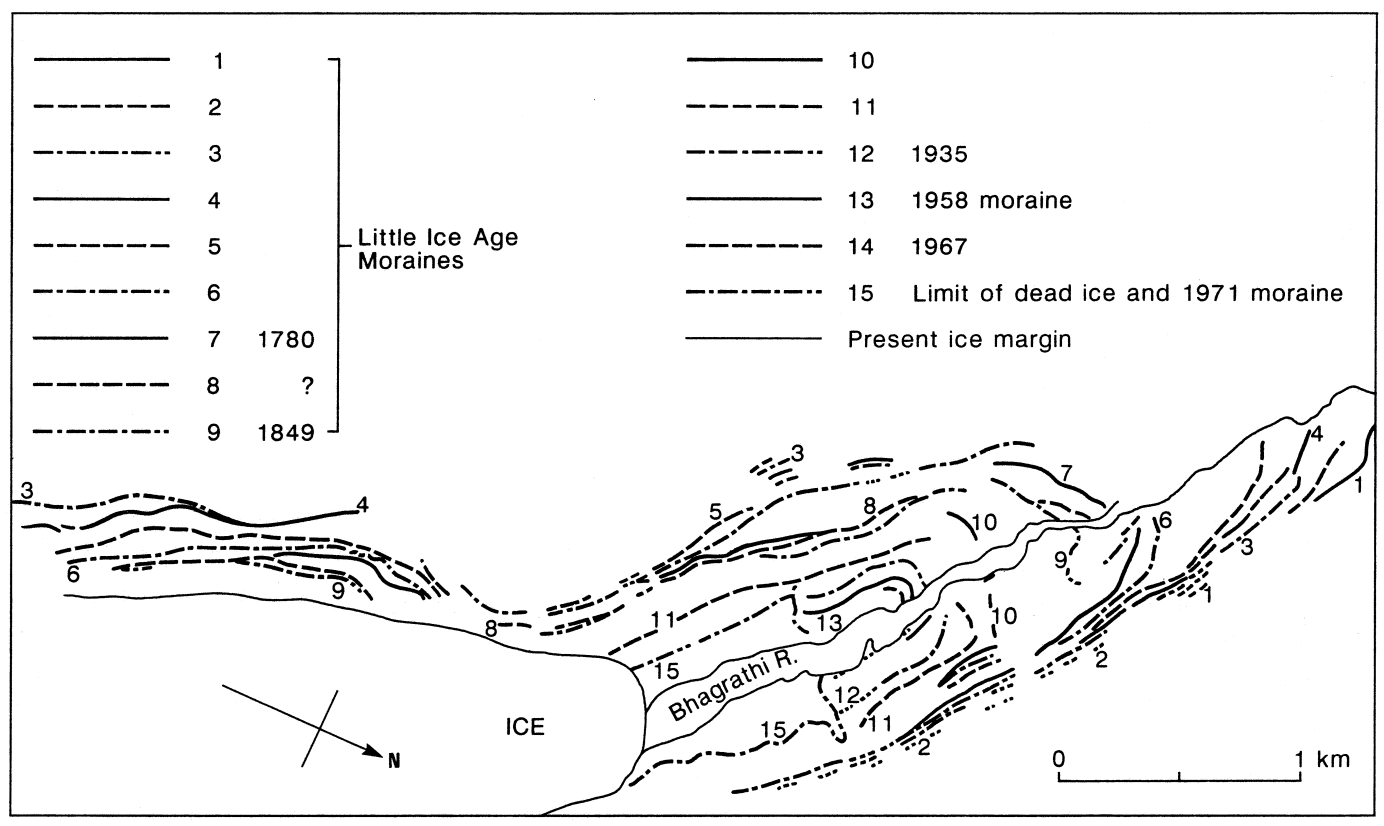

Fig. 4. Map showing the distribution of moraines associated with the retreat of the Gangotri Glacier.

of the meltwater streams. At the mouth of the Raktva Bamak valley (Fig. 1), three moraine ridges are present at heights of ca. $120 \mathrm{~m}$ above the present surface of Gangotri Glacier and $120 \mathrm{~m}$ below the highest lateral moraine level of the Bhagirathi Glacial Stage. These can be traced down the Bhagirathi

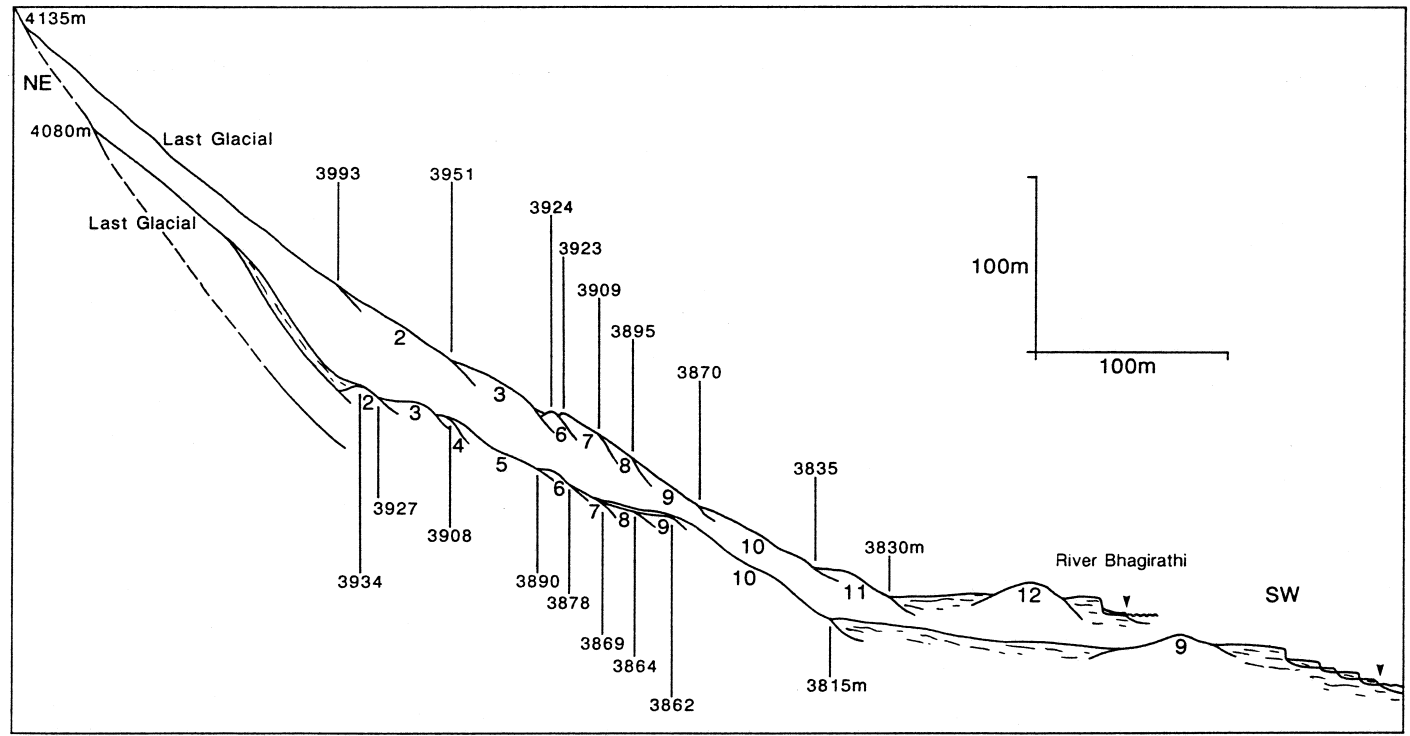

Fig. 5. Relative heights of moraines along selected profiles on the north side of the upper Bhagirathi valley. 


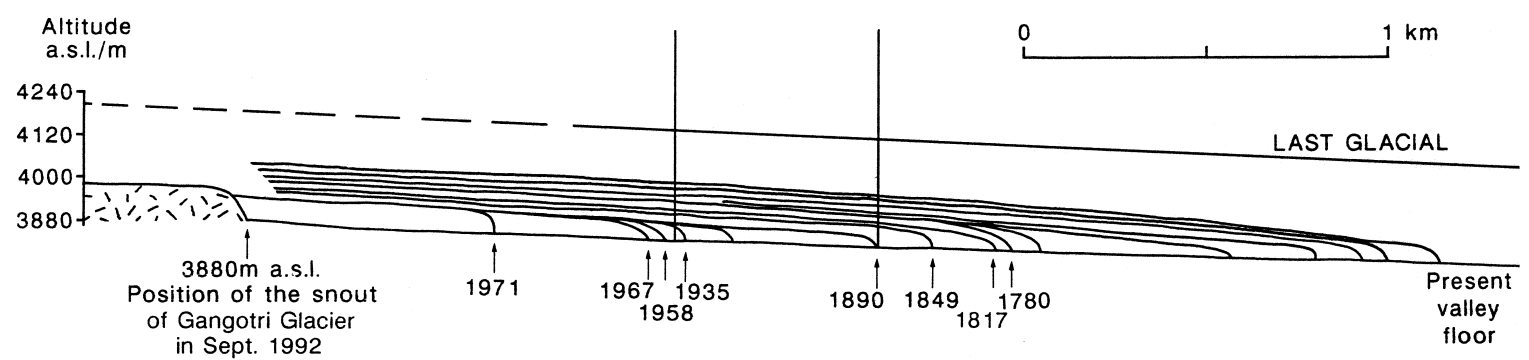

Fig. 6. Reconstructions of former ice positions and thicknesses for the Gangotri Glacier.

valley to Bhujbas (Fig. 3). Sharma and Owen (1996) attribute these moraine ridges to the Shivling Glacial Advance which formed during mid-Holocene times $(<5 \mathrm{ka})$.

Small moraines are inset into the moraines of the Shivling Glacial Advance. Sharma and Owen (1996) attribute these to the Bhujbas Glacial Advance and correlate them with a series of retreats over the last 300 years. These moraines are, therefore, equivalent to the Little Ice Age moraines found elsewhere in the world. Within $1 \mathrm{~km}$ of the snout of Gangotri Glacier, a chaotic assemblage of hummocky moraines and dead ice, with small ponds exist. These features have formed during rapid ice retreat since 1971 (Sharma and Owen, 1996). The geographical distribution and elevations of moraines in this region are shown in Figs. 4 and 5, whereas Fig. 6 is a reconstruction of the former ice thicknesses.

\subsection{Paraglacial fans}

Spectacular paraglacial fans are present in the upper Bhagirathi valley and are intricately associated with the moraines and outwash plains (Fig. 3). Fig. 2 shows the geomorphological characteristics of the fans and their relationship to the moraines within the

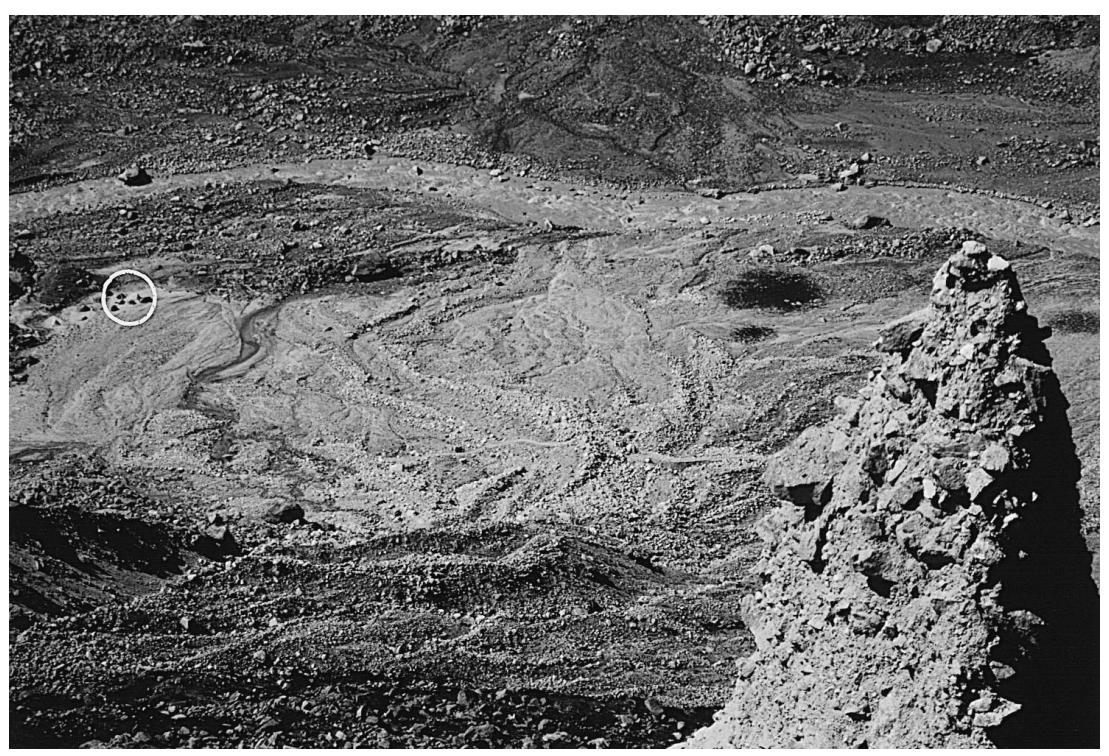

Fig. 7. View looking south across the Bhagirathi river on the surface of Fan B showing typical debris flows. The pinnacle in the bottom right hand corner shows a typical eroded deposit of till that has supplied debris to the paraglacial fan. The circle encloses tents for scale. 
study area. The fans consist of sediment from debris flow, glaciofluvial, fluvial and avalanche processes. The surface of the fans are characterised by a large number of shallow channels with levees, which have gradients ranging from about $20^{\circ}$ at the apex of the fans to $<2^{\circ}$ near the fan toes (Figs. 2 and 7). Small debris flows modify the surface of some of the fans near their heads during the spring and summer snow melt, and during the monsoon rains. Where the fans have been incised by streams, the debris flow deposits can be examined. They have crude down slope stratification and poorly developed fabric. The debris comprises diamictons which have grain size distributions that are extremely poorly sorted, very leptokurtic to extremely leptokurtic and are positively to very positively skewed, with angular clasts. They are virtually indistinguishable from the supraglacial tills from which they are derived. Table 1 compares the particle size characteristics for selected debris flows and glacial sediments. Avalanche processes also contribute large quantities of debris to the surface of the fans, as shown by the small conical piles of fresh sharp rock fragments and organic matter that are distributed across the surface of the fans.

Two main types of fans can be differentiated on the basis of the nature of the sediment transport paths. In the first type, sediment has been eroded from moraines and transported between moraine ridges. Near the apex of these fans, sediment is deposited around moraine ridges incorporating the moraines as inliers within the fans. Fans A and E (Fig. 2) are of this type. Much of the debris which has been transported to Fan E, however, has been supplied by meltwater channels and debris flows from the end moraine of the Meru Glacier. The second type of fan is fed by streams and debris flows which transport debris almost perpendicular to the trend of the moraines. The channels along which debris is transported within these fans has deeply eroded into the lateral moraines, which suggests that the entrenchment accompanies glacial retreat and ice wastage. Fans B, C and D are of this type. All the fans in the study area are being actively incised at their toes by the Bhagirathi River, while only Fan B is deeply entrenched to its head.

\subsection{Glaciofluvial terraces and outwash plain}

Glaciofluvial terraces are present in front of all the recently deglaciated forefields in Garhwal. The terraces are usually within $1 \mathrm{~km}$ of the glacier snout and comprise poorly sorted sand, and rounded to subrounded gravels and pebbles, with sub-horizontal down valley stratification. Four main terraces occur along the forefield of the Gangotri Glacier, and their development is related to the progressive retreat of the Gangotri Glacier (Fig. 2).

Table 1

Particle size characteristics for selected debris flow and till sediments from the upper Bhagirathi valley

\begin{tabular}{|c|c|c|c|c|}
\hline Sample & Mean & Sorting & Kurtosis & Skewness \\
\hline Debris flow (Gangotri) & 6.74 & 5.42 & 2.34 & 0.69 \\
\hline Debris flow (Gangotri) & 6.98 & 7.35 & 5.59 & 1.71 \\
\hline \multirow[t]{4}{*}{ Debris flow near, upper Bhagirathi valley } & 6.88 & 6.68 & 5.63 & 1.58 \\
\hline & 6.77 & 6.85 & 1.74 & 0.51 \\
\hline & 7.21 & 5.29 & 1.90 & 0.05 \\
\hline & 7.76 & 5.54 & 1.81 & 0.42 \\
\hline Lateral moraine, Gangotri & 6.65 & 4.84 & 1.35 & 1.04 \\
\hline \multirow{4}{*}{ Hummocky moraine, upper Bhagirathi valley } & 7.23 & 7.27 & 3.00 & 0.96 \\
\hline & 6.66 & 8.25 & 8.37 & 2.33 \\
\hline & 6.76 & 5.86 & 1.26 & 0.09 \\
\hline & 7.23 & 7.46 & 5.38 & 1.58 \\
\hline Supraglacial debris from the Gangotri Glacier & 6.80 & 5.46 & 3.46 & 1.25 \\
\hline
\end{tabular}

All values are measured in $\phi$ units.

The statistical analysis was undertaken using Folk and Ward (1956). 


\section{Discussion}

The fans in this region formed by paraglacial resedimentation of lateral moraines during and shortly after the Gangotri Glacier retreated. The increased volumes of meltwater associated with deglaciation may have helped increase the rate of erosion and resedimentation. More likely, however, as the glacier began to retreat, the streams began to adjust and grade to the new localised base-level, eroding perpendicular to the moraine ridges. Sediment was transported by mass movement as streams eroded
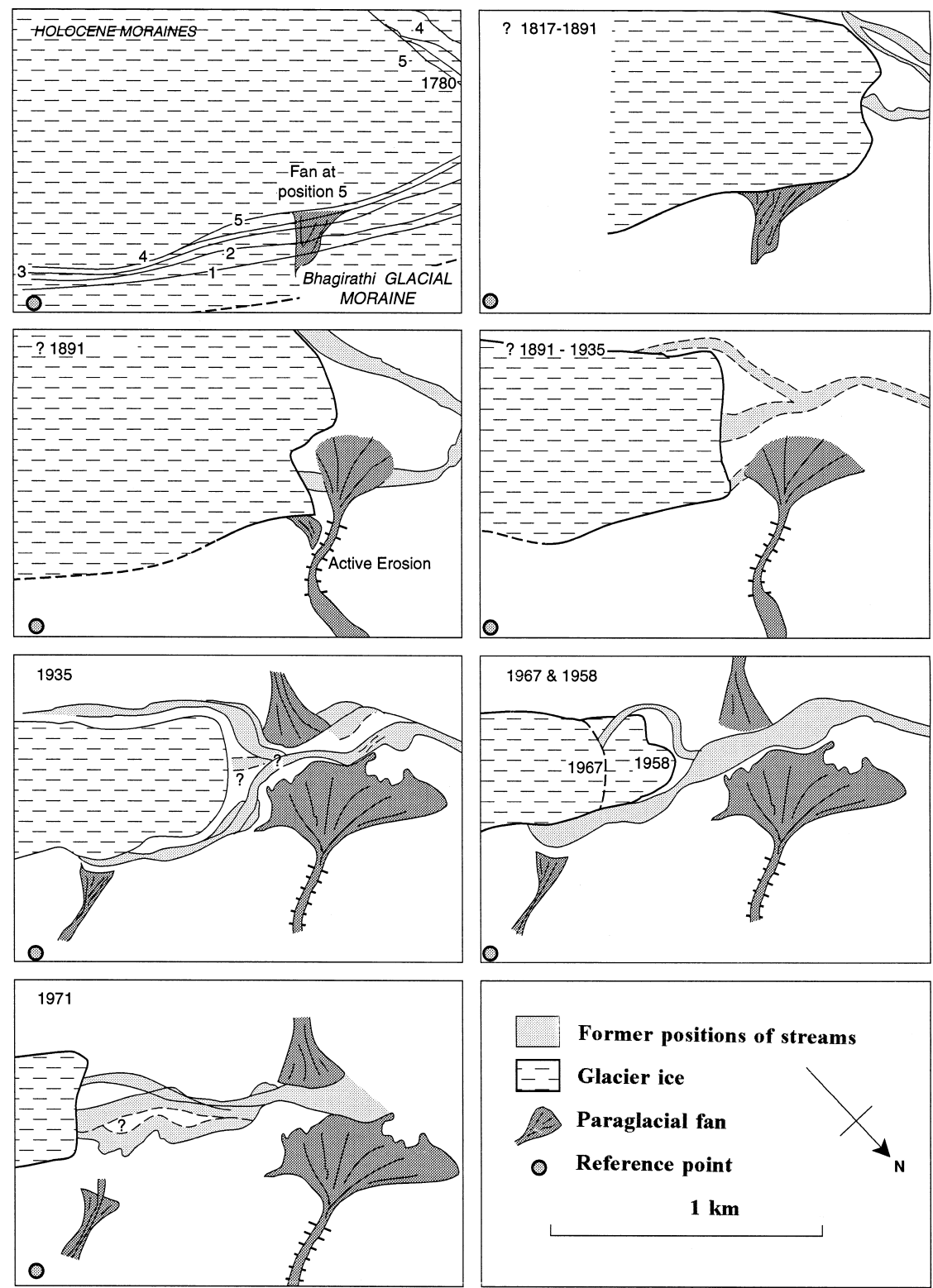

Fig. 8. Sequential development of paraglacial fans in the upper Bhagirathi valley over the last 200 years. 
into the moraines. The steepened moraine slopes collapsed because they were no longer supported by the glacier. Debris flow processes were mainly responsible for the transfer of large amounts of sediment from the moraines to the valley bottom.

The paraglacial fans within this region exhibit different phases of development because of the progressive retreat of the Gangotri Glacier. In this respect, Fan A was the first to form, followed by Fan B. Fans $\mathrm{C}$ and $\mathrm{E}$ are approximately the same age, and are younger than Fan B, while Fan D is the youngest fan in the study area. Fig. 8 shows the progressive development of Fan C over the last 200 years. This fan developed initially across moraine ridges, when the glacier was still thick. As the ice retreated, there was substantial erosion and resedimentation of lateral moraines as streams graded to the new base-level. Within 150 years, the fan had grown in extent from approximately $15,420 \mathrm{~m}^{2}$ to $90,840 \mathrm{~m}^{2}$ in 1935. Fig. 9 shows the relative growth from 1780 to 1990. Since 1935, the fan has extended little, restricted by fluvial erosion at its toe by the Bhagirathi River, although small debris flows have continued to contribute material to its surface. Fan $\mathrm{D}$, to the east of this fan, began to grow as the ice retreated from its 1971 position. In contrast, Fan D is deeply entrenched to its head, indicating that erosion now dominates down valley. This suggests that

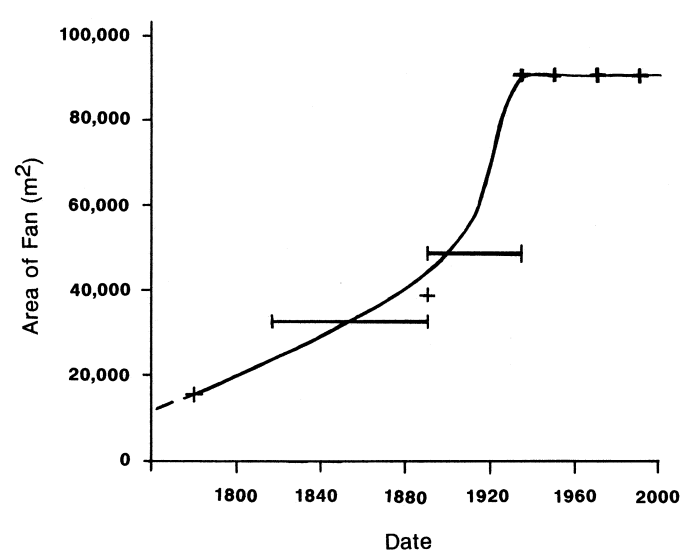

Fig. 9. Graph showing rate of sedimentation of the paraglacial fans in the upper Bhagirathi valley. The error bars show the uncertainty associated with the age of the glacial moraines and hence timing of retreat. aggradation has ceased on this fan and it is being resedimented by fluvial processes. The main streams and debris flows that supplied sediments to its surface have been substantially reduced due to the lowering of slope gradients (presently $<28^{\circ}$ ) or because of the reduced supply of sediment from the main axial stream as moraines have been destroyed and the sediment source has been depleted.

This rapid short-lived period of resedimentation and fan formation supports the finding of other workers such as Ballantyne and Benn (1994) and Ballantyne (1995) in Norway, Ryder (1971b) in south-central British Columbia, Gardner (1982) in the Canadian Rocky Mountains, and Jackson et al. (1982) in the Bow Valley, Alberta. In the upper Bhagirathi valley, the paraglacial fans also undergo modification by fluvial incision after they have formed, and result in fan head entrenchment as the axial streams continue to grade. This is demonstrated by Fan B in the upper Bhagirathi valley. Further landscape modifications occur because the main glaciofluvial streams, in this case the Bhagirathi River, migrate across the proglacial area in response to fluctuating positions of meltwater channels as they exit the glacier and as the main glaciofluvial stream adjusts to the new gradients and is redirected around or through the newly formed moraines.

The preservation of the large lateral moraines which formed during the Bhagirathi Glacial Stage, however, demonstrate that although resedimentation of moraines may be rapid in localised areas, moraine debris may survive for considerable periods of time. Within the study area, the Bhagirathi Glacial Stage moraines are approximately 17,000 years old and further down valley they are about 63,000 years old (Sharma and Owen, 1996). Beyond Bhandargaon, these moraines are discontinuous and have obviously undergone greater degrees of incision. In addition, there is no evidence for moraines older than those of the Bhagirathi Glacial age in Garhwal. In other Himalayan regions, multiple glacial stages have been recognised (Shroder et al., 1993; Owen et al., 1996a), which suggests that pre-Bhagirathi Glacial age glaciations probably effected the Garhwal Himalaya. The lack of preservation of evidence for older glaciations in Garhwal suggests that for periods of more than about 100,000 years, moraines are totally destroyed by resedimentation within this region. 


\section{Conclusion}

Paraglacial resedimentation of moraines is an important and dominant process in the glaciated valleys of the Garhwal Himalaya and is intricately linked with deglaciation. The paraglacial fans in upper Bhagirathi valley illustrate the rapidity of mass movement and fluvial processes in the readjustment of the Himalayan landscape to changes in glaciation. This study shows that the main development of paraglacial fans in this region occurs within approximately 100 years of deglaciation, and there after the fans were modified by small debris flows and eroded by fluvial processes. Within time spans of about 100,000 years, however, any moraines within this area are totally resedimented.

The timing and rates of paraglacial modification in other Himalayan environments have not been studied, but this example provides a model which may be used in other regions. Care must be taken, however, when comparing these results with other regions because regional climates, as well as microclimates, vary considerably throughout the Himalayas and comparisons may not be valid for all regions. The progressive retreat of Himalayan glaciers since the later part of this century (Mayewski and Jeschke, 1979; Mayewski et al., 1980) has probably resulted in paraglacial processes becoming more prolific and dominant throughout the $\mathrm{Hi}$ malayas in recent years. The possibility that global warming may lead to further increases in glacial retreat (Houghton et al., 1990) may further increase the prevalence of paraglacial activity. An understanding of the dynamics of these processes, therefore, is particularly important for hazard mitigation and watershed management, particularly for the accurate calculations of sediment yields in relation to the longevity of reservoirs.

\section{Acknowledgements}

This project was supported by NERC grant GR3/8384 and the University of London Central Research Fund awarded to L.A. Owen, and M.C. Sharma was supported by the Government of India. Pat Fothergill and Ben Richards for carefully reading and commenting on the initial manuscript and Justin Jackyno for drafting Figs. 1 and 4-6.

\section{References}

Ballantyne, C.K., 1995. Paraglacial debris-cone formation on recently-deglaciated terrain. Holocene 5 (1), 25-33.

Ballantyne, C.K., Benn, D.I., 1994. Paraglacial slope adjustment and resedimentation following recent glacier retreat, Fåbergstølsdalen, Norway. Arctic Alpine Res. 26 (3), 255-269.

Burbank, D.W., Kang, C.K., 1991. Relative dating of Quaternary moraines, Rougbuk Valley, Mount Everest, Tibet: implications for an ice sheet on the Tibetan Plateau. Quat. Res. 19, 1-18.

Burke, R.M., Birkeland, P.W., 1979. Reevaluation of multiparameter relative dating techniques and their application to the glacial sequence along the eastern escarpment of the Sierra Nevada, CA. Quat. Res. 11, 21-51.

Church, M.A., Ryder, J.M., 1972. Paraglacial sedimentation: a consideration of fluvial processes conditioned by glaciation. Geol. Soc. Am. Bull. 83, 3059-3071.

Cooke, R.U., Doornkamp, J.C., 1990. Geomorphology in Environmental Management. Oxford Univ. Press, Oxford, $409 \mathrm{pp}$.

Derbyshire, E., Owen, L.A., 1990. Quaternary alluvial fans in the Karakoram Mountains. In: Rachocki, A.H., Church, M. (Eds.), Alluvial Fans: A Field Approach. Wiley, Chichester, pp. 2753.

Folk, R.L., Ward, W.C., 1956. A study in the significance of grainsize parameters. J. Sedimentary Petrol. 27, 3-26.

Gardner, J.S., 1982. Alpine mass wasting in contemporary time: some examples from the Canadian Rocky Mountains. In: Thorn, C.E. (Ed.), Space and Time in Geomorphology. Allen and Unwin, London, pp. 171-192.

Houghton, J.T., Jenkins, G.T., Ephraums, J.J. (Eds.), 1990. Climate Change: The IPCC Scientific Assessment, Cambridge Univ. Press, Cambridge.

Huber, Ernst., 1985. Garhwal-Himalaya-West (Map, 1:150,000). Herausgeben von der, Schweizerischen Stifung für alpine Forschungen.

Jackson, L.E., MacDonald, G.M., Wilson, M.C., 1982. Paraglacial origin for terraced river sediments in Bow Valley, Alberta. Can. J. Earth Sci. 19, 2219-2231.

Lee, J., 1991. Particle-size analysis of the less than $2 \mathrm{~mm}(-1.0$ phi) fraction. Centre for Environment Analysis and Management, Royal Holloway, Univ. of London, 7 pp.

Mayewski, P.A., Jeschke, P.A., 1979. Himalayan and TransHimalayan glacier fluctuations since AD 1812. Arctic Alpine Res. 11 (3), 267-287.

Mayewski, P.A., Pregent, G.P., Jeschke, P.A., Ahmad, N., 1980 Himalayan and Trans-Himalayan glacier fluctuations and the south Asian monsoon record. Arctic Alpine Res. 12 (2), 171-182

Metcalfe, R.P., 1993. Pressure, temperature and time constraints on metamorphism across the main central thrust zone and high Himalayan slab in the Garhwal Himalaya. In: Treloar, P.J., Searle, M.P. (Eds.), Himalayan Tectonics. Geol. Soc. London, Special Publication, 74, pp. 495-509. 
Owen, L.A., 1989. Terraces, uplift and climate in the Karakoram Mountains, Northern Pakistan: Karakoram intermontane basin evolution. Z. Geomorphol. 76, 117-146.

Owen, L.A., 1991. Mass movement deposits in the Karakoram Mountains and western Himalaya. Z. Geomorphol. 35 (4), 401-424.

Owen, L.A., Derbyshire, E., 1989. The Karakoram glacial depositional system. Z. Geomorphol. 76, 33-74.

Owen, L.A., Benn, D.I., Derbyshire, E., Evans, D.J.A., Mitchell, W.A., Thompson, D., Richardson, S., Lloyd, M., Holden, C., 1995a. The geomorphology and landscape evolution of the Lahul Himalaya, Northern India. Z. Geomorphol. 39 (2), 145-174.

Owen, L.A., Sharma, M., Bigwood, R., 1995. Mass movement hazard in the Garhwal Himalaya: the effects of the 20 October 1991 Garhwal earthquake and the July-August 1992 monsoon season. In: McGregor, D.F.M., Thompson, D.A. (Eds.), Geomorphology and Land Management in a Changing Environment. Wiley, Chichester, pp. 69-88.

Owen, L.A., Benn, D.I., Derbyshire, E., Evans, D.J.A., Mitchell, W.A., Richardson, S., 1996a. The Quaternary glacial history of the Lahul Himalaya, Northern India. J. Quat. Sci. 11 (1), $25-42$.
Owen, L.A., Sharma, M., Bigwood, R., 1996b. Landscape modification and geomorphological consequences of the 20 October, 1991 Garhwal earthquake. Z. Geomorphol. 103, 359-372.

Perrott, F.A., Goudie, A.S., 1984. Techniques for the study of glacial fluctuations. In: Miller, K. (Ed.), International Karakoram Project. Cambridge Univ. Press, Cambridge, I, pp. 95-100.

Ryder, J.M., 1971a. The stratigraphy and morphology of paraglacial alluvial fans in south-central British Columbia. Can. J. Earth Sci. 8, 279-298.

Ryder, J.M., 1971b. Some aspects of the morphometry of paraglacial alluvial fans in south-central British Columbia. Can. J. Earth Sci. 8, 1252-1264.

Schweinfurth, U., 1968. Vegetation of the Himalaya. In: Law, B.C. (Ed.), Mountains and Rivers of India. 21st International Geographical Congress, India, pp. 110-136.

Sharma, M.C., Owen, L.A., 1996. Quaternary glacial history of the Garhwal Himalaya, India. Quat. Sci. Rev. 15, 335-365.

Shroder, J.F., Owen, L.A., Derbyshire, E., 1993. The Quaternary glacial history of the Karakoram and Nanga Parbat Himalaya. In: Shroder, J.F. (Ed.), Himalayas to the Sea: Geology, Geomorphology and the Quaternary. Routledge, London, pp. 132158. 